\title{
Obstruction of Justice dalam Pasal 21 Undang-Undang No. 31 Tahun 1999 Tentang Pemberantasan Tindak Pidana Korupsi
}

\author{
Johan Dwi Junianto \\ johanjunianto@yahoo.com \\ Universitas Airlangga
}

\begin{abstract}
In Article 21 of Law Number 31 of 1999 concerning Eradication of Corruption, the law does not explicitly regulate the meaning of the act of "preventing, hindering, or frustrating directly or indirectly", in such provisions so that it is not impossible that there is an error in interpreting the meaning deeds in the provisions of article. The error in question can be in the form of mistakes in determining the classification of actions, when the actions are carried out until the errors in interpreting the norms that are general in nature. To find out about how the norm can be applied, of course it needs to be understood in relation to the material content contained in the legal norms as a whole, namely regarding the meaning and understanding of each act regulated in the provision. Furthermore, regarding how the crime is carried out and can be said to be a criminal offense that fulfills all elements in the provisions of Article 21 of Law No. 31 of 1999 concerning Eradication of Corruption Crimes. In this normative juridical study, it is discussed about the act of obstruction of justice in the provisions of Article 21 of Law No. 31 of 1999 concerning Eradication of Corruption, using the legal approach as well as existing legal concepts to address the problems raised, in addition to that a case approach is also used to find out what legal considerations are used as a basis for evaluating an act hindering the legal process (obstruction of justice) in the provisions of Article 21 of Law No. 31 of 1999 concerning Eradication of Corruption Crimes.
\end{abstract}

Keywords: Criminal acts; Obstruction of justice; Criminal acts of corruption.

\begin{abstract}
Abstrak
Dalam Pasal 21 Undang-Undang Nomor : 31 Tahun 1999 Tentang Pemberantasan Tindak Pidana Korupsi tidak diatur secara tegas mengenai makna dari perbuatan "mencegah, merintangi, atau menggagalkan secara langsung atau tidak langsung", dalam ketentuan tersebut sehingga bukan tidak mungkin terdapat kesalahan dalam mengartikan makna perbuatan dalam ketentuan pasal. Kesalahan yang dimaksud dapat berupa kesalahan dalam menentukan klasifikasi perbuatan, kapan perbuatan dilakukan hingga pada kesalahan-kesalahan dalam menafsirkan norma yang bersifat umum tersebut. Untuk mengetahui tentang bagaimana norma tersebut dapat seharusnya diterapkan, tentunya perlu dipahami terkait dengan materi muatan yang terdapat dalam norma hukum tersebut secara utuh, yakni mengenai makna dan pengertian setiap perbuatan yang diatur dalam ketentuan tersebut. Selanjutnya mengenai bagaimana tindak pidana tersebut dilaksanakan dan dapat dikatakan sebagai sebuah tindak pidana yang memenuhi segala unsur dalam ketentuan pasal 21 Undang-Undang No. 31 Tahun 1999 Tentang Pemberantasan Tindak Pidana Korupsi. Dalam penelitian yang bersifat yuridis normatif ini, dibahas mengenai perbuatan obstruction of justice dalam ketentuan Pasal 21 Undang-Undang No. 31 Tahun 1999 Tentang Pemberantasan Tindak Pidana Korupsi, dengan menggunakan pendekatan perundang-undangan dan juga konsep-konsep hukum yang ada untuk menjawab permasalahan yang diajukan, selain itu digunakan pula pendekatan kasus untuk mengetahui pertimbangan hukum apa yang dijadikan dasar dalam menilai suatu perbuatan menghalangi proses hukum (obstruction of justice) dalam ketentuan Pasal 21 Undang-Undang No. 31 Tahun 1999 Tentang Pemberantasan Tindak Pidana Korupsi.
\end{abstract}

Kata Kunci: Tindak Pidana; Obstruction of justice; Tindak pidana korupsi. 


\section{Pendahuluan}

Penyelenggaraan peradilan pidana oleh semua elemen dalam sistem peradilan ditujukan untuk menegakkan hukum yang berkeadilan dengan senantiasa mendasarkan pada Pancasila sebagai dasar ideologi bernegara. ${ }^{1}$ Dalam sila ke-2 Pancasila yang berbunyi "kemanusiaan yang adil dan beradab", diartikan bahwa setiap manusia haruslah diperlakukan secara adil dan beradab terhadap hak-haknya sebagai warga negara, selain itu juga dalam sila ke-5 Pancasila mengandung makna mengenai konsep keadilan yang secara menyeluruh bagi semua warga negara pada pernyataan "keadilan sosial bagi seluruh rakyat Indonesia". Konsep tersebut sejalan dengan asas equality before the law dalam asas hukum pidana kita, sebagaimana diatur sebagai asas dalam penyelenggaraan kekuasaan kehakiman bahwa pengadilan dalam mengadili setiap warganegara dilaksanakan menurut hukum tanpa memandang ataupun membedakan orang/ warganegara tersebut (Pasal 4 Ayat (1) Undang-Undang No. 48 Tahun 2009 Tentang Kekuasaan Kehakiman).

Dalam proses peradilan yang dilaksanakan khususnya terhadap perkara tindak pidana korupsi, terdapat beberapa dari para pelaku tindak pidana korupsi ataupun yang disangka sebagai pelaku tindak pidana korupsi, melakukan upayaupaya untuk dapat lolos dari jerat hukum ataupun tidak dikenai proses hukum atau peradilan. Dalam salah contoh satu kasus yang masih ada dalam ingatan kita pada tahun 2010 ketika dilakukan proses persidangan kasus dengan terdakwa Anggodo Widjojo, pada saat persidangan terdakwa tiba-tiba mengeluh mengalami sakit pada bagian kepala dan nyeri disekujur tubuh, sehingga terdakwa menyatakan tidak mampu untuk melanjutkan persidangan, namun setelah dokter memeriksa kondisi kesehatan terdakwa, terdakwa dalam kondisi normal saja. ${ }^{2}$ Berpura-pura sakit tersebut merupakan cara yang paling mudah untuk menghindari proses

\footnotetext{
1 Lihat Ketentuan Pasal 2 Ayat (2) Undang-Undang Nomor 48 Tahun 2009 Tentang Kekuasaan Kehakiman (Lembaran Negara Republik Indonesia Nomor 157 Tahun 2009, Tambahan Lembaran Negara Nomor 5076,yang berbunyi : "Peradilan negara menerapkan dan menegakkan hukum dan keadilan berdasarkan Pancasila”.

${ }^{2} \ldots$ __ Kpk Tak Lekang (KPG (Kepustakaan Populer Gramedia) 2013).[42-44].
} 
hukum, karena orang yang dihadirkan dalam keadaan sakit tidak dapat dilakukan penyidikan, penuntutan maupun pemeriksaan persidangan.

Salah satu contoh adalah kasus korupsi proyek pengadaan E-KTP (Kartu Tanda Penduduk Elektronik) yang melibatkan Mantan Ketua Dewan Perwakilan Rakyat (DPR-RI) Setya Novanto, yang dalam proses Penyidikan tersangka beberapa kali menolak untuk menghadiri panggilan pemeriksaan dari Komisi Pemberantasan Korupsi (KPK) dengan alasan sakit, ${ }^{3}$ selain itu setelah dilakukan upaya paksa tersangka kembali menghindari petugas KPK yang hendak melakukan penangkapan, hingga kemudian banyak drama yang dimainkan sehingga Setya Novanto berusaha untuk lolos dari jerat hukum. Upaya-upaya dari Setya Novanto tersebut memanglah tidak mengherankan bagi sebagian orang oleh karena politisi partai Golkar tersebut beberapa kali lolos dari kasus yang melibatkan dirinya, bahkan sering dikenal dengan sebutan "sinterklas". ${ }^{4}$ Padahal korupsi sebagai kejahatan luar biasa (extra ordinary crime) dalam upaya pemberantasannya diperlukan pula cara yang luar biasa dalam penanganannya. khususnya dalam tahap penyelidikan, tindak pidana korupsi ini, terdapat beberapa institusi penyidik yang berwenang untuk menangani proses penyidikan terhadap pelaku tindak pidana yang terkait dengan tindak pidana korupsi ini. Termasuk berbagai institusi PPNS jika dikaitkan dengan berbagai kejahatan yang terkandung unsur-unsur korupsi sesuai dengan bidang tugas masing-masing serta sesuai dengan peraturan perundang-undangan yang menjadi dasar hukum masing-masing. ${ }^{5}$

Adanya kasus tersebut justru memberikan dinamika hukum tersendiri dalam penegakkan hukum pidana di Indonesia, oleh karena dalam peraturan perundangundangan hukum pidana, tindakan menghalangi proses hukum telah secara tegas diatur dalam ketentuan Pasal 21 Undang-Undang Nomor 31 Tahun 1999 Tentang

3 Fachrur Rozie, 'Setya Novanto: 2 Kali Jadi Tersangka, 2 Kali Masuk Rumah Sakit' (Liputan 6, 2017) <https://www.liputan6.com/news/read/3165661/setya-novanto-2-kali-jadi-tersangka2-kali-masuk-rumah-sakit>.

4 Abraham Utama, 'Setya Novanto Pernah Disebut "Sinterklas Yang Kebal Hukum"' (BBC Indonesia, 2017) < https://www.bbc.com/indonesia/indonesia-41501085>.

5 Ifrani, 'Tindak Pidana Korupsi Sebagai Kejahatan Luar Biasa' (2017) IX Al'Adl.[323]. 
Pemberantasan Tindak Pidana Korupsi (Lembaran Negara Nomor 140 Tahun 1999 sebagaimana telah diubah dengan Undang-Undang Nomor 20 Tahun 2001 Tentang Perubahan Atas Undang-Undang Nomor 31 Tahun 1999 Tentang Pemberantasan Tindak Pidana Korupsi (Tambahan Lembaran Negara Nomor 3874), yang mana dalam ketentuan tersebut diatur mengenai jenis-jenis tindakan yang dapat dikenai ketentuan pidana mengenai tindakan yang bertujuan untuk menghalangi ataupun merintangi dari dilaksanakannya suatu proses peradilan, baik untuk diri sendiri ataupun orang lain baik secara langsung ataupun tidak langsung.

Dalam perkembangannya menyimak dari perjalanan kasus E-KTP yang melibatkan Setya Novanto, kemudian dilakukan proses hukum terhadap Frederich Yunadi yang merupakan pengacara Setya, dan juga Bimanesh Sutarjo, Dokter Rumah Sakit Medika Permata Hijau yang dtetapkan sebagai tersangka atas kasus menghalangi proses penyidikan terhadap Setya Novanto. ${ }^{6}$ Selain kasus tersebut terdapat pulu beberapa kasus sebelumnya yang terkait dengan tindak pidana/ delik menghalangi proses hukum/ peradilan antara lain kasus Anggodo Widjojo, kasus Manatap Ambarita, kasus Miryam S. Haryani dan kasus O.C. Kaligis walaupun yang disebut terakhir diperiksa terhadap dugaan suap yang dilakukan namun perkembangan ditemukan usaha atau upaya untuk menghalangi proses peradilan. Adanya kasus-kasus tersebut tentunya memberikan perbedaan dalam pelaksanaan penegakkan hukum di Indonesia mengingat jarang sekali seseorang di hadirkan diddepan persidangan dengan disangka atau didakwa melanggar ketentuan mengenai perbuatan menghalangi proses hukum, padahal secara nyata hal tersebut merupakan salah satu bentuk tindak pidana yang dapat merusak upaya penegakkan hukum.

Berdasarkan pada hal-hal tersebut diatas dalam penelitian ini rumusan masalah yang akan dibahas yakni: Kapan suatu tindakan dianggap sebagai obstruction of justice, berdasarkan ketentuan Pasal 21 Undang-Undang No. 31 Tahun 1999 Tentang Pemberantasan Tindak Pidana Korupsi dan Apa ratio decidendi dalam putusan

\footnotetext{
${ }^{6}$ Ridho Insan Putra, 'KPK Tetapkan Fredrich Yunadi Dan Bimanesh Sebagai Tersangka' (Liputan 6.com, 2018) <https://www.liputan6.com/news/read/3222150/kpk-tetapkan-fredrich-yunadi-dan-bimanesh-sebagai-tersangka $>$.
} 
yang terkait dengan tindakan obstruction of justice berdasarkan ketentuan Pasal 21 Undang-Undang No. 31 Tahun 1999 Tentang Pemberantasan Tindak Pidana Korupsi. Dalam penelitian ini hukum Normatif ini digunakan metode pendekatan berdasarkan peraturan perundang-undangan (statute approach), dan pendekatan berdasarkan peristiwa/ kasus (case approach), serta pendekatan secara konsep (conseptual approach). Konsep hukum yang dimaksud yakni konsep mengenai tindak pidana obstruction of justice yang termuat dalam norma atau ketentuan Pasal 21 UndangUndang Nomor 31 Tahun 1999 Tentang Pemberantasan Tindak Pidana Korupsi.

\section{Obstruction of Justice Sebagai Suatu Tindak Pidana.}

Tindakan obstruction of justice atau diartikan pula perbuatan yang bermaksud untuk 'menghalangi proses hukum' atau 'tindak pidana menghalangi proses hukum'. Sesuai dengan istilahnya sebagai suatu tindak pidana atau perbuatan pidana, tentunya didalam perbuatan tersebut haruslah memenuhi syarat-syarat sehingga tindakan atau perbuatan yang dilakukan termasuk dalam suatu tindak pidana. Dalam ajaran hukum pidana, suatu tindak pidana dirumuskan berdasarkan unsur-unsur yang ada sehingga dapat dikatakan sebagai suatu tindak pidana, Simons dalam menjelaskan perumusan mengenai delik yakni sebagai: ${ }^{7}$

"Een Strafbaar gestelde onrechmatige (wederrechtelijke), met schuld in verband staade handeling vaneen toerekeningsvatbaar person”.

Perumusan tersebut, apabila dibagi berdasarkan unsur-unsur yang ada di dalam suatu tindak pidana, pendapat Simons tersebut menurut Satochid Kertanegara dapat dibagi berdasarkan unsur sebagai berikut: ${ }^{8}$

1. Tindakan yang dapat dihukum;

2. Tindakan yang dilakukan bertentangan dengan hukum;

3. Tindakan dengan kesalahan yang berhubungan dengan;

4. Tindakan yang dilakukan oleh orang yang dapat dihukum (toerekeningsvatbaar).

Berdasarkan pada pendapat tersebut perbuatan obstruction of justice yang dirumuskan dalam Pasal 21 Undang-Undang No. 31 Tahun 1999 Tentang

\footnotetext{
${ }^{7}$ Satochid Kartanegara, Hukum Pidana (Kumpulan Kuliah) (Balai Lektur Mahasiswa 1998).[91].

${ }^{8}$ ibid.[91].
} 
Pemberantasan Tindak Pidana Korupsi, berdasarkan sifat perbuatannya adalah telah memenuhi semua unsur delik dalam pendapat tersebut oleh karena, dalam rumusan unsur Pasal 21 Pasal 21 Undang-Undang No. 31 Tahun 1999 Tentang Pemberantasan Tindak Pidana Korupsi, mengatur mengenai perbuatan yang dikategorikan sebagai osbtruction of justice, yang secara formil perbuatan tersebut adalah perbuatan yang dilarang dan mengandung sanksi pidana didalamnya. Berdasarkan sifatnya perbuatan obstruction of justice, ditujukan agar suatu proses hukum terhadap sesorang pelaku tindak pidana menjadi terhambat atau terhenti, maka sudah barang tentu bahwa perbuatan yang dilakukan adalah perbuatan pada saat dilakukannya proses peradilan yang meliputi penyelidikan, penyidikan, penuntutan maupun pemeriksaan persidangan, yang dilaksanakan oleh pejabat yang berwenang.

Dalam hal ini pelaku mengetahui bahwa pejabat yang melaksanakan proses tersebut adalah pejabat yang memiliki kewenangan untuk melakukannya, ataupun mungkin apabila pelaku tidak mengetahui dengan benar mengenai pejabat yang melaksanakan kewenangan tersebut, maka pelaku tetap bertanggung jawab atas tidak dipenuhinya permintaan atau perintah tersebut, hal tersebut sebagaimana dalam Arrest Hoge Raad tertanggal 23 Mei 1932, N.J. 1932 halaman 1209 W. 12503 yang menyatakan: ${ }^{9}$

"Voldoende is dat dader moet begrijpen, dat hij die de vordering doet, een ambteenaar is, bevoegd tot het doen der vordering. Bij een naat de uiterlijke omstandigheheden bevoegd optreden, komt het risico, of de vorderende persoon interdaad bevoegd is, voor rekening van dengene, die de vordering trotseert."

Yang artinya :

"Kiranya cukup jika pelaku harus mengerti, bahwa orang yang mengajukan permintaan adalah seseorang pegawai negeri yang berwenang untuk mengajukan permintaan tersebut. Jika berdasarkan keadaan lahiriah terdapat keragu-raguan mengenai apakah orang yang mengajukan permintaan sebenarnya merupakan orang yang berwenang untuk mengajukan permintaan seperti itu atau tidak, maka akibatnya harus ditanggung oleh orang yang tidak memenuhi permintaannya." (H.R. 11 Maret 1895, W. 6637; 28 Oktober 1895, W. 6734).

${ }^{9}$ Lamintang Dkk, Delik-Delik Khusus : Kejahatan Terhadap Kepentingan Hukum Negara (Sinar Grafiika 2010).[647]. 
Berdasarkan yurisprudensi tersebut, adanya kesengajaan atau niat dari si petindak atau pelaku perbuatan dalam delik obstruction of justice, diwujudkan dari adanya pengetahuan dari pelaku bahwa perbuatan yang dilakukan memiliki hubungan kausa antara perbuatan dengan perintah jabatan dari pejabat yang berwenang untuk melakukan pemeriksaan, penyitaan atau penahanan dalam kaitannya dengan tindakan penyidikan ataupun penuntutan terhadap suatu perkara pokok yang sedang dihadapi. Berdasarkan sifatnya sebagai delik formil, perwujudan dari niat tersebut adalah, dengan dilakukannya perbuatan persiapan untuk melakukan perbuatan menghalangi proses hukum, atau perbuatan yang secara nyata menghalangi perintah jabatan sedang dilaksanakan oleh pejabat yang berwenang, sehingga seorang yang dengan perintah jabatan diperintahkan untuk melakukan sesuatu hal dianggap telah mengetahui bahwa hal tersebut merupakan bagian dari proses hukum yang sedang dilaksanakan.

Menyitir pendapat dari Ellen Podgor, dalam Shinta Agustina, yang dalam pendapatnya menyatakan sebagai berikut: ${ }^{10}$

"For prosecutors, the crime of obstruction of justice is an offense that is relatively easy to prove. This is in part because the statue does not require an actual obstruction. Under the omnibus clause of \$1503, obstruction of justice marely require an "endeavor" to obstruct of justice".

Berdasarkan uraian tersebut diatas sudah jelas kirannya bahwa dalam tindak pidana meghalangi proses hukum (obstruction of justice) selain ditinjau dari perbuatannya yang telah memuat adanya kesalahan dari si pelaku yang harus dianggap sebagai kesengajaan sebagai maksud, serta perbuatan tersebut secara nyata telah bertentangan dengan peraturan perundang-undangan yang berlaku maka terhadap perbuatan tersebut dapat dikatakan sebagai perbuatan pidana/ tindak pidana.

\section{Tindakan Obstruction Of Justice Dalam Ketentuan Pasal 21 Undang-Undang} No. 31 Tahun 1999 Tentang Pemberantasan Tindak Pidana Korupsi.

Ketentuan Pasal 21 Undang-Undang No. 31 Tahun 1999 Tentang

${ }^{10}$ Shinta Agustina Dkk, Obstruction Of Justice : Tindak Pidana Menghalangi Proses Hukum Dalam Upaya Pemberantasan Korupsi (Themis Book 2015).[31]. 
Pemberantasan Tindak Pidana Korupsi berbunyi :

"Setiap orang yang dengan sengaja mencegah, merintangi, atau menggagalkan secara langsung atau tidak langsung penyidikan, penuntutan, dan pemeriksaan disidang pengadilan terhadap tersangka atau terdakwa ataupun para saksi dalam perkara korupsi, dipidana dengan pidana penjara paling singkat 3 (tiga) tahun dan paling lama 12 (dua belas) tahun dan atau denda paling sedikit Rp. 150.000.000,00 (seratus lima puluh juta rupiah) dan paling banyak Rp.600.000.000,00 (enam ratus juta rupiah)”.

Unsur perbuatan dalam ketentuan tersebut adalah dengan sengaja mencegah, merintangi, atau menggagalkan secara langsung atau tidak langsung, apabila dilihat berdasarkan karakteristik perbuatan obstruction of justice, sebagaimana dijelaskan oleh Kendall, yang menyatakan perbuatan atau percobaan tersebut dinyatakan sebagai tindak pidana menghalangi proses hukum, apabila terpenuhi 3 (tiga) unsur penting yaitu : (1) Tindakan tersebut menyebabkan tertundanya proses hukum (pending judicial proceedings); (2) Pelaku mengetahui tindakannya atau menyadari perbuatannya (knowledge of pending proceedings); (3) Pelaku melakukan atau mencoba tindakan menyimpang dengan tujuan untuk mengganggu atau mengintervensi proses atau administrasi hukum (acting corruptly with intent), Selain itu dalam beberapa peradilan di Amerika di tambahkan satu syarat lagi yakni haruslah dapat dibuktikan terdakwa memiliki "motif" untuk melakukan tindakan yang dilakukan. ${ }^{11}$

Berdasarkankarakteristik tersebut dapat diketahuibahwaketentuan sebagaimana tersebut dalam Pasal 21 Undang-Undang No. 31 Tahun 1999 Tentang Pemberantasan Tindak Pidana Korupsi merupakan pengertian secara umum dari tindakan obstruction of justice tersebut, sehingga ketentuan mengenai perbuatan obstruction of justice, yang tidak diatur dalam ketentuan Pasal 22 Undang-Undang No. 31 Tahun 1999 Tentang Pemberantasan Tindak Pidana Korupsi yang mengatur mengenai kewajiban saksi untuk memberikan keterangan yang benar dan Pasal 23 Undang-Undang No. 31 Tahun 1999 Tentang Pemberantasan Tindak Pidana Korupsi mengenai tindak pidana yang diatur dalam peraturan pidana umum yakni dalam Pasal 220 KUHP

11 ibid. [83]. 
memberikan laporan/ pengaduan palsu, Pasal 231 KUHP menyembunyikan benda sitaan, Pasal 421, 422 dan 429 KUHP mengenai tindak pidana dalam jabatan, secara tidak langsung termasuk dalam pengertian perbuatan yang diatur dalam Pasal 21 Undang-Undang No. 31 Tahun 1999 Tentang Pemberantasan Tindak Pidana Korupsi.

Apabila dirumuskan berdasarkan unsur-unsurnya dalam ketentuan Pasal 21 Undang-Undang No. 31 Tahun 1999 Tentang Pemberantasan Tindak Pidana Korupsi, termuat unsur-unsur sebagai berikut :

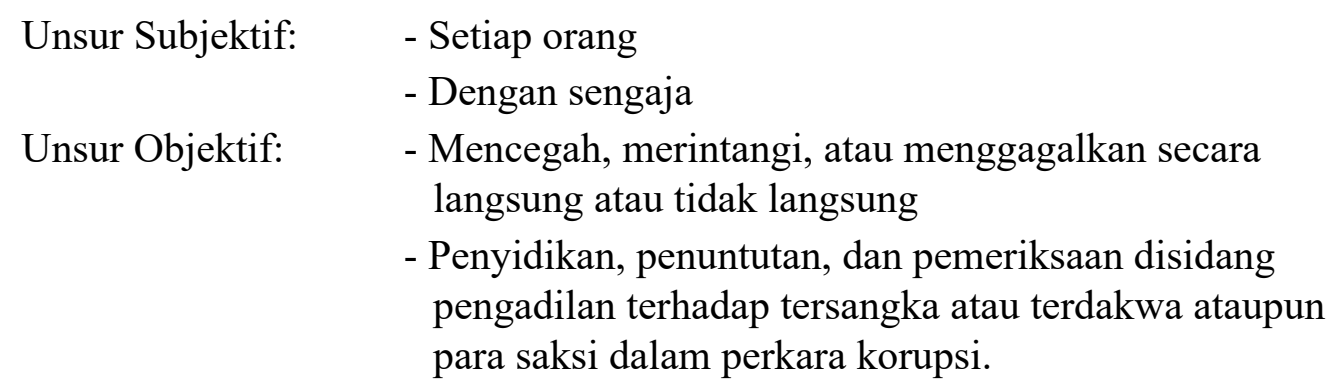

Yang dimaksud dengan unsur subjektif dalam hal ini, menurut Pendapat Satochid Kertanegara merupakan unsur-unsur yang ada pada diri si pelaku yaitu berupa: ${ }^{12}$

a. Toerekeningsvatbaarhet atau pertanggung jawaban pidana dari si pelaku;

b. Schuld, atau kesalahan yang ada pada diri si pelaku.

Pertanggung jawaban pidana dari pelaku disini dimaksudkan adalah pelaku sebagai subjek hukum baik orang perorangan, ataupun badan hukum yang dapat dimintai pertanggung jawaban pidana, tanpa adanya alasan dari si pelaku sehingga tidak dapa dikenai pidana. Lebih jauh Elwi Danil dalam pembahasannya mengenai permasalahan subjek hukum dalam tindak pidana korupsi yang mana dinyatakan bahwa subjek tindak pidana korupsi tidak pernah diatur secara khusus berdasarkan kualifikasi tertentu atau selalu dinyatakan dengan perumusan "barangsiapa" atau dalam Undang-Undang No. 31 Tahun 199 Tentang Pemberantasan tindak pidana korupsi dirumuskan dengan "setiap orang" sehingga dapat diartikan siapa saja, namun terdapat perbedaan pendapat di kalangan penegak hukum, bahwa subjek

\footnotetext{
${ }^{12}$ Kartanegara (n 7).Op.Cit.[247].
} 
hukum dalam tindak pidana korupsi adalah pegawai negeri, sedangkan diluar itu haruslah dikeluarkan dari ketentuan mengenai undang-undang korupsi tersebut. ${ }^{13}$

Bahwa berkaitan dengan permasalahan tersebut, sebenarnya subjek hukum atau pelaku tindak pidana dalam ketentuan Pasal 21 Undang-Undang No. 31 Tahun 1999 Tentang Pemberantasan Tindak Pidana Korupsi, semestinya adalah pelaku itu sendiri yang pada saat melakukan perbuatan sedang dikenai atau dilaksanakan proses penyidikan, penuntutan, pemeriksaan sidang terhadapnya ataupun pelaku lain yang berkaitan dengan hal tersebut. Dalam ketentuan ini pelaku sebagai subjek hukum dalam tindak pidana ini tidaklah dapat dikualifikasikan sebagai orang yang sedang menjalani proses hukum ataupun orang lain yang berkepentingan dalam proses hukum yang dilaksanakan, hal tersebut dimaksudkan agar ketentuan ini dapat menjangkau semua pihak-pihak dalam upaya menjaga agar terhadap pelaksanaan penyidikan, penuntutan dan pemeriksaan di sidang pengadilan dapat dilaksankan sebagaimana mestinya.

Permasalahan selanjutnya yang muncul adalah terkait dengan subjek hukum dalam delik obstruction of justice, yakni apakah seorang pelaku tindak pidana korupsi dapat dikenakan ketentuan sebagaimana dalam ketentuan Pasal 21 UndangUndang No. 31 Tahun 1999 Tentang Pemberantasan Tindak Pidana Korupsi, terhadap permasalahan tersebut kiranya memang dalam salah satu unsur pasal ketentuan yakni : "setiap orang” tidak dikualifikasikan dalam bentuk pelaku tertentu, namun dalam penerapannya tentu saja perlu diperhatikan asas-asas dalam hukum pidana dan hukum acara pidana yang berlaku. Dalam hukum pidana dikenal adanya prinsip bahwa seorang tersangka atau calon tersangka dilarang untuk memberikan keterangan yang memberatkan dirinya atau yang pada akhirnya justru membuktikan kesalahannya, prinsip tersebut dikenal dengan self incrimination. ${ }^{14}$ Berdasarkan ketentuan Pasal 117 KUHAP secara jelas dinyatakan bahwa tersangka dalam memberikan keterangan harus "bebas", berdasarkan "kehendak" dan kesadaran

13 Elwi Danil, Korupsi : Konsep, Tindak Pidana, Dan Pemberantasannya (Rajawali Pers 2016).[105-106].

${ }^{14}$ Munir Fuady Dkk, Hak Asasi Tersangka Pidana (Kencana 2015).[56-57]. 
nuraninya, sehingga jawaban atau keterangan yang diberikan oleh tersangka dihadapan penyidik, diberikan tanpa tekanan dari siapapun juga dan dengan bentuk apapun. ${ }^{15}$ Berdasarkan ketentuan tersebut sehingga seorang tersangka tidaklah diharuskan untuk mengatakan hal-hal secara benar yang dialaminya, oleh karena hak tersangka untuk memberikan keterangan yang bebas sesuai dengan kehendak. Berdasar pada hal tersebut apabila dikaitkan dengan teori "kriminalisasi diri" atau self incrimination tentu saja seorang tersangka dalam memberikan keterangan adalah keterangan yang tidak membuat dirinya dapat dipidana, sehingga hak untuk "ingkar" atau "mungkir" adalah dibenarkan sesuai ketentuan tersebut. Dalam hal dilakukannya perbuatan yang dapat menghalangi proses hukum, apabila diartikan bahwa "hak ingkar" tadi merupakan kebohongan untuk menutupi perbuatannya, maka tidaklah tepat apabila perbuatan tersangka tersebut dianggap sebagai "obstruction of justice”,

Sedangkan schuld atau kesalahan disini adalah berkaitan dengan perbuatan 'dengan sengaja' tadi sebagaimana dalam unsur subjektif kedua unsur pasal tersebut, yakni sengaja sebagai maksud atau tujuan yang mana apabila mengacu pada adanya teori perkiraan kehendak (voorstelling theory), maka seorang dianggap sengaja atau memiliki kehendak apabila dia dapat membayangkan atau memperkirakan bahwa suatu akibat itu pasti terjadi atau mungkin terjadi karena perbuatannya. Dalam konteks perbuatan obstruction of justice dalam ketentuan Pasal 21 Undang-Undang No. 31 Tahun 1999 Tentang Pemberantasan Tindak Pidana Korupsi tersebut, tidaklah perlu dibuktikan apakah sesorang berkehendak agar proses hukum baik itu penyidikan, penuntutan dan pemeriksaan sidang menjadi tercegah, terintangi atau tergagalkan dengan adanya perbuatan yang dilakukan oleh si pelaku, namun cukuplah bahwa dengan adanya perbuatan yang dilakukan si pelaku mengetahui perbuatan tersebut dapat mencegah, merintangi atau menggagalkan suatu proses hukum yang sedang dilaksanakan. ${ }^{16}$

${ }^{15}$ M Yahya Harahap, Pembahasan Permasalahan Dan Penerapan KUHAP : Penyidikan Dan Penuntutan (2nd edn, Sinar Grafika 2010).[332-333].

${ }^{16}$ Shinta Agustina Dkk (n 10)., Op Cit.[113-114]. 
Selanjutnya berkaitan dengan unsur objektif, atau hal-hal yang ada diluar diri si petindak yang menurut Satochid Kertanegara dapat berupa :

a. Perbuatan;

b. Akibat;

c. Masalah (omstandigheden).

Perbuatan dalam hal ini adalah unsur perbuatan dalam ketentuan Pasal 21 Undang-Undang No. 31 Tahun 1999 Tentang Pemberantasan Tindak Pidana Korupsi, yakni perbuatan mencegah, merintangi, atau menggagalkan secara langsung atau tidak langsung. Dalam prakteknya, perbuatan tersebut haruslah dapat dibuktikan mengenai perbuatan-perbuatan konkrit yang dilakukan sehingga dalam perbuatan tersebut telah memenuhi unsur pidana. Dalam peraturan mengenai tindak pidana korupsi tidak mengenal adanya percobaan perbuatan yang dirumuskan dalam ketentuan Pasal 2, 3, Pasal 5 sampai dengan Pasal 14, sebagaimana dijelaskan dalam ketentuan Pasal 15 Undang-Undang No. 31 Tahun 1999 Tentang Pemberantasan Tindak Pidana Korupsi, penjelasan dalam pasal tersebut hanya dinyatakan : "Ketentuan ini merupakan aturan khusus karena ancaman pidana pada percobaan dan pembantuan tindak pidana pada umumnya dikurangi 1/3 (satu per tiga) dari ancaman pidananya". Apabila mengacu pada ketentuan tersebut sehingga terhadap ketentuan dalam Pasal 21 Undang-Undang No. 31 Tahun 1999 Tentang Pemberantasan Tindak Pidana Korupsi, masih dapat diterapkan ketentuan mengenai percobaan tersebut.

Sebelum dilakukannya suatu perbuatan pastilah didahulu dengan perbuatan permulaan ataupun perbuatan persiapan yang ada, sehingga dapat terlaksana suatu perbuatan, atau dalam hal ini adalah perbuatan mencegah, merintangi, atau menggagalkan secara langsung atau tidak langsung. Elwi Danil dalam pendapatnya mengenai percobaan tindak pidana korupsi memberikan penjelasan bahwa dalam suatu delik formil, ${ }^{17}$ sesorang dapat disangkakan telah melakukan percobaan tindak pidana korupsi bilamana orang tersebut telah memulai melakukan tindakan atau

${ }^{17}$ Ketentuan dalam Pasal 21 Undang-Undang No. 31 Tahun 1999 Tentang Pemberantasan Tindak Pidana Korupsi. 
perbuatan yang dilarang oleh undang-undang, maka telah ada suatu permulaan tindakan pelaksanaan (van uitvoeringshandeling), sehingga setelah adanya perbuatan permulaan tindakan pelaksanaan tersebut maka seorang pelaku tindak pidana sudah dapat dikenai pidana. ${ }^{18}$

Perbuatan dalam perumusannya sebagai suatu perbuatan/ tindak pidana (strafbaar feit), menurut Simons haruslah memuat beberapa unsur yakni: ${ }^{19}$

1. Suatu perbuatan manusia (menselijk handelingen). Dengan handeling dimaksudkan tidak saja "een doen" (perbuatan), akan tetapi juga "een nalaten" (mengakibatkan);

2. Perbuatan itu (yaitu perbuatan dan mengakibatkan) dilarang dan diancam dengan hukuman oleh undang-undang;

3. Perbuatan itu harus dilakukan oleh seseorang yang dapat dipertanggung jawabkan, artinya dapat dipersalahkan karena melakukan perbuatan tersebut.

Berdasarkan penjelasan tersebut, suatu perbuatan mencegah, merintangi dan menggagalkan haruslah memuat unsur-unsur perbuatan yang ada dalam suatu tindak pidana sebagaimana dalam rumusan Simons mengenai strafbaar feit. Bahwa perbuatan mencegah, merintangi dan menggagalkan yang dimaksudkan sebagai perbuatan manusia (menselijk handelingen) dalam ketentuan Pasal 21 UndangUndang No. 31 Tahun 1999 Tentang Pemberantasan Tindak Pidana Korupsi, secara nyata telah dilarang dan diancam dengan pidana. Terhadap perbuatan atau tindakan manusia tersebut dilihat dari adanya akibat aktif, tindakan tersebut dapat merupakan: ${ }^{20}$ a. Een bewuste handeling ( tindakan dengan kesadaran );

b. Een gewilde handeling (tindakan disertai dengan kemauan).

Sehingga apabila perbuatan dilakukan dilakukan secara tidak sadar maka bukan merupakan tindak pidana dan tidak dapat dikenai pertanggung jawaban pidana.

Dalam perbuatan mencegah, merintangi dan menggagalkan secara langsung dan tidak langsung dalam ketentuan Pasal 21 Undang-Undang No. 31 Tahun 1999 Tentang

\footnotetext{
${ }^{18}$ Elwi Danil (n 13).Op.Cit. [127].

${ }^{19}$ Kartanegara (n 7).Op Cit.[65].

${ }^{20}$ ibid.[66-67].
} 
Pemberantasan Tindak Pidana Korupsi, tentunya perbuatan tersebut haruslah dilakukan setelah adanya suatu perintah tertentu dalam pelaksanaan penyidikan, penuntutan dan pemeriksaan sidang, sebagai unsur keadaan yang ada dalam ketentuan tersebut, sehingga seseorang yang melakukan perbuatan tersebut haruslah mengetahui bahwa perbuatan mencegah, merintangi dan menggagalkan secara langsung dan tidak langsung adalah ada hubungannya dengan proses penyidikan, penuntutan dan pemeriksaan sidang yang sedang dilaksanakan atau memiliki motif untuk melakukan perbuatan tersebut.

Dari bentuk-bentuk perbuatan yang di rumuskan dalam pasal di atas kriteriakriteria perbuatan menghalangi proses peradian tindak pidana korupsi sebagaimana dijelaskan oleh Khairul Fadli adalah: ${ }^{21}$

a. Perbuatan mencegah tersebut adalah pada waktu penegak hukum sedang atau akan melakukan proses peradilan dalam perkara korupsi, pelaku tindak pidana telah melakukan perbuatan tertentu dengan tujuan agar proses peradilan tidak dapat dilaksanakan dan usaha pelaku tindak pidana tersebut memang berhasil;

b. Merintangi dapat kita defenisikan mempersulit suatu tindakan yang akan dilakukan. Yang dimaksud dengan perbuatan pelaku tindak pidana tersebut adalah pada waktu penegak hukum sedang atau akan melakukan proses peradilan dalam perkara korupsi, pelaku tindak pidana telah melakukan perbuatan tertentu dengan tujuan agar proses peradilan yang sedang berlangsung terhalang untuk di laksanakan, dan apakah perbuatan tersebut dapat tercapai atau tidak, bukan merupakan syarat. Jadi di sini cukup membuktikan ada indikasi upaya yang mengarah kepada perbuatan menggagalkan atau menghambat proses peradilan;

c. Yang dimaksud dengan perbuatan pelaku tindak pidana tersebut adalah pada waktu penegak hukum sedang atau akan melakukan proses peradilan dalam perkara korupsi, pelaku tindak pidana telah melakukan perbuatan tertentu dengan tujuan agar proses peradilan yang sedang dilaksanakan tidak berhasil dan usaha pelaku tindak pidana tersebut memang berhasil. Menggagalkan

\footnotetext{
${ }^{21}$ Markhy S Gareda, 'Perbuatan Menghalangi Proses Peradilan Tindak Pidana Korupsi Berdasarkan Pasal 21 UU No. 31 Tahun 1999 Juncto UU No. 20 Tahun 2011 (Lex Crimen Vol. IV/No. 1/Jan-Mar/2015).' (2015) Vol. IV Lex Crimen.[138].
} 
adalah membuat suatu tindakan tidak mempunyai akibat atau membuat suatu tindakan yang telah di lakukan menjadi suatu kegagalan.

Bahwa Dalam perbuatan mencegah, merintangi dan menggagalkan secara langsung dan tidak langsung dalam ketentuan Pasal 21 Undang-Undang No. 31 Tahun 1999 Tentang Pemberantasan Tindak Pidana Korupsi, merupakan delik formil, sehingga delik tersebut telah selesai dilakukan tanpa mensyaratkan adanya akibat yang ditimbulkan dari perbuatan, yakni menjadi tercegah, terintangi atau tergagalkannya suatu penyidikan, penuntutan dan pemeriksaan sidang yang sedang dilaksanakan, namun cukup dengan melakukan perbuatan mencegah, merintangi dan menggagalkan yang berdasarkan pengetahuannya, perbuatan tersebut dapat menghalangi atau menggalkan suatu suatu penyidikan, penuntutan dan pemeriksaan sidang maka perbuatan sudah dianggap selesai atau delik selesai (vooltoid).

\section{Ratio Decidendi Putusan Terhadap Pebuatan Obstruction Of Justice}

Berdasarkan pertimbangan hakim (ratio decidendi) yang termuat dalam ketiga Putusan Pengadilan yang telah diuraikan, yakni terhadap : Putusan Mahkamah Agung Republik Indonesia Nomor Putusan : 684 K/Pid.Sus/2009, tanggal 16 Juli 2010, dalam perkara atas nama Terdakwa Manatap Ambarita, SH, kemudian Putusan MahkamahAgung Republik Indonesia Putusan Nomor : 168 K/Pid.Sus/2011, tanggal 03 Maret 2011, atas nama Terdakwa Anggodo Widjojo, dan Putusan Pengadilan Tindak Pidana Korupsi Pada Pengadilan Tinggi DKI Jakarta Nomor Putusan : 23/Pid.Sus-TPK/2018/PT.DKI, tanggal 5 Oktober 2018 dalam perkara atas nama Terdakwa Fredrich Yunadi, dapat diketahui bahwa hakim ataupun Majelis hakim memiliki pendapat atau pandangan yang berbeda dalam mengartikan makna unsur “dengan sengaja” dalam ketentuan Pasal 21 Undang-Undang No. 31 Tahun 1999 Tentang Pemberantasan Tindak Pidana Korupsi, dalam Putusan Mahkamah Agung Republik Indonesia Putusan Nomor : 168 K/Pid.Sus/2011, tanggal 03 Maret 2011, atas nama Terdakwa Anggodo Widjojo, Majelis berpendapat bahwa yang dimaksud “dengan sengaja” adalah berkenaan dengan kehendak atau niat jahat Terdakwa melakukan perbuatannya tersebut yang melawan hukum, dengan kata lain maksud 
atau tujuan dari perbuatannya tersebut untuk melakukan kejahatan atau tindak pidana, dalam hal ini adalah perbuatan mencegah, merintangi atau menggagalkan secara langsung atau tidak langsung penyidikan, penuntutan dan pemeriksaan di sidang Pengadilan.

Hal tersebut berbeda dengan pendapat atau pandangan hakim atau Majelis hakim dalam Putusan Pengadilan Tindak Pidana Korupsi Pada Pengadilan Tinggi DKI Jakarta Nomor Putusan : 23/Pid.Sus-TPK/2018/PT.DKI, tanggal 5 Oktober 2018, yang memaknai "dengan sengaja" dalam perbuatan yang dilakukan oleh terdakwa sebagai kesengajaan secara kepastian keinsyafan, hal tersebut dikarenakan Majelis memandang bahwa perbuatan yang dilakukan oleh terdakwa berdasarkan fakta persidangan terlihat nyata mempunyai niat jahat (mens rea). Hal itu terbukti dalam perbuatannya (actus reus) yang berusaha sedemikian rupa untuk membela kliennya yaitu Setya Novanto. Majelis hakim memandang bagaimana kapasitas Fredrich yakni sebagai Pengacara atau bagian dari salah satu perangkat proses peradilan yang seharusnya menjunjung tinggi hukum dan keadilan. Tetapi fakta hukumnya Fredrich justru malah melakukan perbuatan melawan hukum.

\section{Kesimpulan}

Tindak pidana Obstruction Of Justice dalam ketentuan Pasal 21 UndangUndang No. 31 Tahun 1999 Tentang Pemberantasan Tindak Pidana Korupsi, diwujudkan dalam bentuk semua perbuatan yang bersifat mencegah, merintangi dan menggagalkan secara langsung dan tidak langsung, dengan tidak mensyaratkan adanya akibat yang ditimbulkan dari perbuatan tersebut, yakni menjadi tercegah, terintangi atau tergagalkannya suatu penyidikan, penuntutan dan pemeriksaan sidang yang sedang dilaksanakan, namun cukup dengan melakukan perbuatan mencegah, merintangi dan menggagalkan yang berdasarkan pengetahuannya, perbuatan tersebut dapat menghalangi atau menggalkan suatu suatu penyidikan, penuntutan dan pemeriksaan sidang maka perbuatan sudah dianggap selesai (vooltoid). 


\section{Daftar Bacaan}

\section{Buku}

Dkk Lamintang, Delik-Delik Khusus : Kejahatan Terhadap Kepentingan Hukum Negara (Sinar Grafiika 2010).

Elwi Danil, Korupsi : Konsep, Tindak Pidana, Dan Pemberantasannya (Rajawali Pers 2016).

Harahap MY, Pembahasan Permasalahan Dan Penerapan KUHAP : Penyidikan Dan Penuntutan (2nd edn, Sinar Grafika 2010).

Kartanegara S, Hukum Pidana (Kumpulan Kuliah) (Balai Lektur Mahasiswa 1998).

Kpk Tak Lekang (KPG (Kepustakaan Populer Gramedia) 2013).

Munir Fuady Dkk., Hak Asasi Tersangka Pidana (Kencana 2015).

Shinta Agustina Dkk, Obstruction Of Justice : Tindak Pidana Menghalangi Proses Hukum Dalam Upaya Pemberantasan Korupsi (Themis Book 2015).

\section{Jurnal}

Ifrani, 'Tindak Pidana Korupsi Sebagai Kejahatan Luar Biasa' (2017) IX Al’Adl.

Gareda MS, 'Perbuatan Menghalangi Proses Peradilan Tindak Pidana Korupsi .Berdasarkan Pasal 21 UU No. 31 Tahun 1999 Juncto UU No. 20 Tahun 2011 (Lex Crimen Vol. IV/No. 1/Jan-Mar/2015).' (2015) Vol. IV Lex Crimen.

\section{Laman}

Abraham Utama, 'Setya Novanto Pernah Disebut "Sinterklas Yang Kebal Hukum"” (BBC Indonesia, 2017) <https://www.bbc.com/indonesia/ indonesia-41501085>.

Fachrur Rozie, 'Setya Novanto: 2 Kali Jadi Tersangka, 2 Kali Masuk Rumah Sakit' (Liputan 6, 2017) <https://www.liputan6.com/news/read/3165661/setyanovanto-2-kali-jadi-tersangka-2-kali-masuk-rumah-sakit>.

Putra RI, 'KPK Tetapkan Fredrich Yunadi Dan Bimanesh Sebagai Tersangka' (Liputan 6.com, 2018) < https://www.liputan6.com/news/read/3222150/kpktetapkan-fredrich-yunadi-dan-bimanesh-sebagai-tersangka>. 


\section{Perundang-undangan}

Undang-Undang Nomor 48 Tahun 2009.

Undang-Undang No. 31 Tahun 1999.

HOW TO CITE: Johan Dwi Junianto, 'Obstruction of Justice dalam Pasal 21 Undang-Undang No. 31 Tahun 1999 Tentang Pemberantasan Tindak Pidana Korupsi’ (2019) Vol. 2 No. 3 Media Iuris. 